\title{
Service Innovation Strategic Consensus: A Lesson from the Islamic Banking Industry in Indonesia
}

\author{
Muafi MUAFI ${ }^{1}$, Erlina DIAMASTUTI ${ }^{2}$, Argo PAMBUDI ${ }^{3}$
}

Received: August 01, 2020 Revised: September 20, 2020 Accepted: October 05, 2020

\begin{abstract}
This study aims to analyze the agreement of service innovation using contingency approach (manager personality, organizational structure) moderated by leadership agility. The study has been carried out on Islamic banking companies' managers in Indonesia, from East Java and Yogyakarta region using purposive sampling technique with questionnaire and interviews as the method of data collection. The total number of respondents in the sample is 184. This sample is then analyzed using Euclidience Distance Simple Regression and Simple Regression Moderation method. The results prove that: (1) there is a partial fit between incremental strategy with reactive personality and mechanical organizational structure, which increases the service performance; (2) there is a partial fit between radical strategy with proactive personality and organic organizational structure, which increases the service performance; (3) leadership agility is able to strengthen the fit of the relationship between incremental innovation strategy and reactive personality toward service performance; (4) leadership agility is able to strengthen the fit the relationship between radical innovation strategy and proactive personality toward service performance; (5) leadership agility is able to strengthen the fit of the relationship between incremental innovation strategy and mechanical organizational structure toward service performance; and (6) leadership agility is able to strengthen the fit of the relationship between radical innovation strategy and organic organizational structure toward service performance
\end{abstract}

Keywords: Personality, Organizational Structure, Leadership Agility, Service Innovation, Service Performance

JEL Classification Code: D8, L1, L2, L22

\section{Introduction}

Currently, Islamic banking is facing a number of challenges amid the Covid-19 pandemic. The condition of Islamic banking industry could detoriate earlier than the conventional banking industry; which may reduce the competitiveness of Islamic banking. This is because many people move their funds to conventional banks. Some problems faced by Islamic banking industry are

${ }^{1}$ First Author and Corresponding Author. Professor, Department of Management, Business and Economics Faculty, Universitas Islam Indonesia [Postal Address: JI. SWK Ringroad Utara Condong Catur, Yogyakarta, 55283, Indonesia] Email: muafi@uii.ac.id

${ }^{2}$ Department of Accounting, Economic and Business Faculty, Universitas Internasional Semen Indonesia, Indonesia

${ }^{3}$ Department of Public Administration, Social Sciences Faculty, Universitas Negeri Yogyakarta, Indonesia

(c) Copyright: The Author(s)

This is an Open Access article distributed under the terms of the Creative Commons Attribution Non-Commercial License (https://creativecommons.org/licenses/by-nc/4.0/) which permits unrestricted non-commercial use, distribution, and reproduction in any medium, provided the original work is properly cited. liquidity problems and non-performing financing (NPF) ratios, so that they lose revenue from financing and profit sharing because some customers enter a period of default. It is commonly known that Islamic banks operate without relying on interest, but it operates with profit sharing and margin systems (Republika, May 2020). The risk of macro conditions is naturally affected with the concept of Islamic businesses. First, the basic concept of Islamic business is that it must be fair, balanced, and maslahat. Second, the concept of Islamic business must be fair because of the principle of profit sharing (Finansial Bisnis, May 2020).

Although the government has provided relaxation for banking customers, including for Islamic banking, Islamic banks are currently required to think creatively and smartly, not giving up easily, and must be smart enough to take advantage of all the benefits of existing policies and opportunities by having strategies and policies that can attract its customers who are predominantly Islamic (Republika, July 2020). In terms of financing aspects, Islamic banking is also expected to be able to provide the best solutions for its customers, such as restructuring, additional financing 
periods, or provide a grace period of payment. In terms of funding aspects, Islamic banking must be able to attract customers to save their money in the form of savings, current accounts, and deposits (Republika, July 2020).

The existence of the external environmental pressure requires Islamic banking managers to have a service innovation strategy that is right on target so that it can be implemented efficiently and effectively (Kartika, et al., 2020). If Islamic banking wants to get out of a downturn then Islamic banking managers cannot and should not use old methods in marketing their products and services, as well as in managing their companies. It is because of the fact that the Covid-19 pandemic has deconstructed the Islamic banking system and order which was running normally so far. Islamic banking managers must immediately adapt to the Covid-19 pandemic and new normal era (in Indonesia) both incrementally and radically for improving the company service performance. Incremental innovation strategy can be done since it is used to bring in small changes to the existing processes or services, and it rarely makes an impact on changes in organizational structure. Otherwise, radical innovation strategy is done to make changes fundamentally and introduce completely new ways in the process of organization and services (Muluk 2008; Hilda 2014).

In implementing a service innovation strategy, Islamic banking should consider a contingency approach, so that it is able to further improve the performance of the company (Hodge, et al., 2003; Muafi \& Kusumawati, 2020), such as the manager's personality (Allport, 1937; Muafi, et al., 2020; Ashton, 1998; Kickul \& Gundry 2002) and organizational structure of the company (Schuler \& Jackson 1987; Streers, 1977; Robbins, 1991). Another important matter that becomes a fundamental problem is the need for companies to have high leadership agility from each leader (Lediju 2016; Joiner 2019; Joiner 2009a; 2009b; Joiner, Josephs 2007), especially in Islamic banks (Muafi \& Uyun 2018). They must be able to lead the company effectively in a time of rapid and complex environmental changes (Joiner, 2009a; 2009b; 2009c). This study uses contingency approach, because the service innovation strategy that is chosen to face certain situations depend on the type of the situation. In other words, it is contingent on the situation, especially during Covid- 19 pandemic and new normal situation.

\section{Literature Review}

\subsection{Personality and Service Innovation Strategy}

Allport (1937) defined personality as "the dynamic organization within the individual of those psychophysical systems that determine his unique adjustments to his surrounding environment". Personality is also the total number of innate or hereditary tendencies with various influences from the environment and education that shape it. Although there is not a single accepted definition for all personality theories yet, it can be said that personality is related to the nature that contributes to individual differences in behaviour, the consistency of behaviour over time, and the stability of behaviour throughout a situation. Personality has a unique nature characteristics because it can be considered common to several groups or carried by all species, although the pattern for each individual has significant difference (Koeswara, 1991). It can be concluded that personality is a relatively permanent characteristic pattern and unique characteristics that provide consistency and individuality of a person's behaviour (Feist \& Feist 2008; Koeswara 1991; Suryabrata 2005; Robbins \& Judge, 2013; Jannah, 2016; Soebachman 2011).

In different typologies, (Dubrin, 1996; Crant, 1995; 1996, 2000; Crant \& Bateman, 2000; Chiew \& Braver 2016; 2011; 2013; 2014) divided personality into two types: proactive and reactive. Proactive personality is defined as the personal disposition of someone who is never limited by environmental pressure, thus he is able to create the required changes in the environment. This occurs because of the interaction between people and their surrounding environment. Proactive personality is characterized as as a personality which is smart in seeing opportunities, have active ideas and initiatives, resilient in dealing with changes, and brave enough to face risks (Crant 1995; 1996, 2000; Crant \& Bateman 2000). On the other hand, reactive personality comes into action primarily because of the stimulus beforehand and the presence of disturbance, so that they tend to react in the task of achieving goals. The characteristics of someone with reactive personality are lesser ability to see opportunities, rigid, prefer to avoid risks, and reach for results when facing threats (Chiew \& Braver, 2016; 2011; 2013; 2014). A person who has a reactive personality will react spontaneously when there is a threat from the external environment which pressures him to act against his values. It is also added by Chiew \& Braver, 2016 ; 2011; 2013; 2014) that reactive behavior will change if it is required, but people with reactive personality tend to blame things on other circumstances or people.

Bateman \& Crant (1993) found that proactive personality will be able to influence company performance. On the contrary, the research findings from Ashton (1998) stated that someone who has a reactive personality can reduce organizational performance. Regarding the strategic orientation of the company, it turns out that a manager's personality can influence the way of thinking and strategic orientation to make strategic decisions in improving organizational performance. When someone has a proactive personality, he will have compatibility by implementing prospector strategic orientation in improving organizational performance. Kickul \& Gundry (2002) concluded that prospector strategy can be used as a key weapon in choosing and implementing 
strategies related to the proactive personality of the manager. When there is a mistake in implementing the strategies, the organizational performance will decrease. Innovation is always required so that managers can increasingly face the pressure of a threatening and hostile external environment (Wu et al., 2018). A prospector strategy means that managers are increasingly encouraged to look for new opportunities both in finding markets, producing products, technology, and new services to continue innovating. Managers must be able to explore opportunities and create innovative change. Creativity and innovation are necessary so that the company can continue to survive and even have improved performance. The opposite of the prospector strategy is the defender strategy.

Defender strategy is a corporate strategy in maintaining existing markets by offering low prices (low cost leadership) (David, 2001). It is also added by Ahadiat (2003) that when a company runs a prospector strategy, it means that it is almost always constantly looking for market opportunities, and always experimenting on potential responses from developing environmental trends. The company can be the creator of change and can create uncertainty for its competitors. The company's attention places too much emphasis on the innovation aspect, so efficiency cannot be fully achieved and considered. Instead, the defender strategy is run by companies that have a narrow product-market domain. The top managers of this type of organization must be highly skilled in the area of organizational operations. They tend to not explore opportunities outside the domain. As a result of this narrow focus, organization will rarely make major changes in technology, structure, and method of operation. The company emphasizes more on improving the efficiency of operations that have already been carried out.

Ramdani et al. (2017) found that when companies implement a cost leadership strategy with a stable environment, company managers will generally be confronted with personality consciousness. Conversely, company managers who have an openness to experience personality will tend to be faced with a dynamic environment so that it has a higher performance level. Nadkarni \& Herrmann (2010) in their research recommended that proactive managers will always have a flexibility strategy. This is because the manager's personality can reduce or even increase the orientation of strategic flexibility that he has decided. Managers must be proactive, flexible, and quick in responding to changing environments. In the study conducted by Aronson et al. (2008), it is stated that a team that develops innovation will work in a context with high uncertainty.

Empirically, it turns out that there is a role of the leader's personality in the success of two different types of New Product Development teams: radical and incremental. Using the five-factor personality model as a framework, the results of the study concluded that NPD leaders must have emotional awareness and stability for their success. In addition, it depends on the type of innovation to be chosen. It is strongly supported that the NPD team who works on radical innovation would benefit from openness. Radical NPD teams operate under market conditions and technical uncertainty. A more open leader must easily encourage and handle new ideas which are needed to manage radical innovation. The research results from Aronson et al. (2008) are also supported by Waheed \& Dastgeer (2019), who stated that managers who have a proactive personality will tend to have radical creativity, and vice versa.

H1. The higher the degree of fit between incremental strategy and reactive personality, the higher the service performance would be.

$\boldsymbol{H}$ 2. The higher the degree of fit between radical strategy and proactive personality, the higher the service performance would be.

\subsection{Organizational Structure and Service Innovation Strategy}

The high demand of the Islamic banking business has made an impact on the difficulty of companies to build flexible and innovative organizational structures. The turbulence in the digitalization of information technology forces organization to be more responsive and proactive to have innovative and communicative changes (Kartika et al. 2020). When a company has a bureaucratic and mechanistic organizational structure, it will be hit by the pressure of a volatile external environment. It also works the other way round; when a company chooses an organic organizational structure, the company will be more flexible in anticipating environmental changes that occur outside the company. In fact, there is an appropriate way when an organization wants to design its organizational structure. Negandhi (1975) recommended to study about the characteristics that occur in bureaucratic rules as well as the reasons and consequences of the formation of organizational structure when manager wants to design the organization. This is because it will have an impact on the behavior and strategic decision making of the manager. Therefore, it is expected to have an impact on the effectiveness and efficiency of the organization in the long term.

Robbins (1991) emphasized that organizational structure will follow organization's strategy. Organizations that formulate and implement strategies appropriately will be able to produce increased organizational performance. Therefore, a fit between the organizational structure and organizational strategy is required. From the beginning, Chandler (1962) has described the relationship pattern between strategic formulation, administrative issues, and organizational performance. In formulating organizational strategy, the 
company will be confronted with new administrative issues. When organizational performance decreases, the company should establish a new organizational structure so that organizational performance can be targeted for improvement. It should be noted that bigger companies will be required to add more power by giving new positions. This will have an impact on the wider decision making distance. On the one hand, increasing decentralization in organizations will often be able to achieve effectiveness and efficiency. Employees will be happy because there is frequent transparent, innovative reciprocal communication, and that organizational performance should improve even if there is no guarantee (Steers, 1980; Kumari, 2018).

It is known that organizational structure can be divided into two, namely mechanistic and organic structures. Both of these typologies have opposing continuums and different characteristics (Setiawan \& Novotasari, 2018). Mechanistic and organic are two opposing poles of the continuum which have characteristics that differ from one another. Mechanistic organizational structure have the characteristics of: (1) more rigid; (2) the environment faced tends to be stable and predictable; (3) have more emphasis on specialization; (4) the clarity of rights, obligations, and responsibilities of the position; (5) the existence of structure hierarchy, authority, and vertical communication flow; and (7) emphasizes the aspects of efficiency and is more formal because everyone is controlled and supervised by one supervisor so that the range of control is small. Whereas, organic organizational structure is characterized as: (1) flexibility; (2) volatile environment; (3) non-specialization; (4) More flexible and lateral communication flow; and (5) knowledge that can be sourced from anywhere and not only be consumed by top level management (Setiawan \& Novotasari, 2018; Hall, 1972: Robbins, 1991; Hage, \& Aiken, 1962; Robbins, Coulter, 2012).

The research results from Covin \& Slevin (1989) found that high organizational performance will be achieved when the company can control hostile environment by creating internal administrative structure and organic organizational structure. This result is supported by Dewar and Dutton (1986) who stated that in adopting radical innovation, bigger companies tend to have more technical specialization. The results found no relationship between adoption of innovation types and decentralized decision making, managerial attitudes toward change, and information on the external parties. Company leaders who try to adopt technical process innovation do not need to worry in modifying the centralization of decision making, managerial attitudes, and information on external parties (Kumari, 2018). This also applies equally to managers who try to adopt other types of innovation. It is emphasized that all of these still need human capital that functions as a technical specialist and facilitator in the adoption of technical innovations.
Furthermore, in overcoming business growth bottlenecks, companies must have knowledge about the types of innovations that must be adopted. Contingency approach will always be related to incremental and radical innovation characteristics that is reflected in technological innovation, managerial innovation, institutional innovation, and marketing innovation in various stages of business growth. Companies must choose the right innovation strategy that is in accordance with the stages of their life cycle (Hui \& Qing-xi, 2006). The recommendation from the study conducted by Hui \& Qing-xi (2006) explained that the innovative strategic decision for technology intensive company needed to pay attention to several stages. In the early stages or decline, companies must adopt radical innovations for technology, management, institutions, and marketing. In the growth stage, companies must adopt radical innovations for institutions, and incremental innovation for technology, management, and marketing. Lastly, in the maturity stage, companies must adopt incremental innovations for institutions, management, and marketing, but incremental and radical innovations will apply to technology (Hui \& Qing-xi, 2006).

H3. The higher the degree of fit between incremental strategy and mechanical organizational structure, the higher service performance would be.

H4. The higher the degree of fit between radical strategy and organic organizational structure, the higher service performance would be.

\subsection{Service Innovation Strategy (Incremental vs. Radical)}

Companies should consider the aspects of internal capability in addition to the external environment. This is very important considering the business strategy that is implemented must focus on both aspects (Armstrong, 2003). Miles \& Snow (1978) introduced a more comprehensive typology of strategy by dividing it into four: prospector, analyzer, defender, and reactor. Linked with human resource management literature, Schuler \& Jackson (1987) introduced three strategies which refer to Porter's strategy: innovation, quality enhancement, and cost reduction (low cost). The inherent characteristic of Porter's strategy classification is similar to the one classified by Miles and Snow. Defender (Miles and Snow, 1978) is similar to low cost and efficiency (Porter). On the contrary, prospector (Miles and Snow, 1978) is similar to differentiation/innovation (Porter, Miller and Friesen) (Kumar et al., 1997).

The use of incremental and radical strategies has also become a matter of debate among managers, especially in companies having cross-border operations (Sen \& Ghandforoush, 2018; Banerjee \& Cole, 2011). When an 
organization makes changes in services and processes that are not prominent and large, means that the company has carried out an incremental innovation which is not expected to have a significant impact on the existing organizational structure. On the other hand, when a company makes a radical change, it means that there are fundamental changes which are completely different and new, both in the process and services offered in a routine, varied, and instrumental way (Muluk, 2008; Hilda, 2014; Soleh, 2008). In radical innovation, it requires high costs and relatively long time for it to be accepted by the market. Companies must be careful in order not to deal with failures (Hartanto \& Sugandha, 2019). The research findings from Sen and Ghandforoush (2018) strengthened that IT managers in India believe that radical innovation can be considered as a growth strategy that aims to increase competitive advantage. This can accelerate economic growth in other developing countries. It is affirmed by Abiodun (2017) that a country's economic growth is driven by innovation and entrepreneurship. The results of the study conducted by Gronum et al. (2012) explained that product innovation, process innovation, and administrative innovation all have impacts on the improvement of company performance. Radical innovation mediates the relationship between process, product, and administrative innovation on company performance.

On the other hand, incremental innovation mediates the relationship between process and product innovation and company performance. The research conducted by Gronum et al. (2012) found no evidence that incremental innovation mediates the relationship between administrative innovation and company performance. However, innovation is needed to improve the company's performance and competitiveness (Gronum et al., 2012). With the increase of international competition and rapid technological changes, companies are advised to innovate because innovation is going to be very important for companies that are technology intensive, thus they will have a sustainable competitive advantage (Hui \& Qing-xi, 2006).

The main focus of this study is service performance that is measured from (Cronin \& Taylor 1992; 1994; Dharmayanti, 2006; Lestari \& Laode, 2018) customer satisfaction and customer loyalty based on the company service performance that is provided to its customers. Customers look for information when they interact with service provider by conducting evaluation on the provided services. The principle is that customers value an operational activity from the part that is seen and understood by the customers only when the moment of truth process occurs (Lestari \& Laode, 2018). Service performance must be a very important factor to be considered by every banking industry in order to be able to present a good moment of truth in the minds of customers who are expected to decide the determinants of service quality. Cronin and Taylor
(1994) suggested five service performance indicators or SERVPERF, namely; time, accessibility, completeness, courtesy, and responsiveness.

\subsection{The Moderation Role of Leadership Agility}

The moderating role of leadership agility in analyzing the appropriateness of the relationship between the company's business strategies in improving the performance of banking services is an interesting strategic issue that needs to be studied. This is important since some research findings reveal that leadership can moderate the influence of contingency variables with organizational performance (Yeh et al., 2016; Ximenes et al., 2019; Sari, 2013; Hutagalung, 2016). Muafi and Uyun (2018) found that leadership agility can be used to increase organizational innovation and reduce imitation behavior. Leaders must be able to seize opportunities amid increasing uncertainty and complexity, and they must have priorities for success (Muafi \& Uyun, 2018; Joiner, Josephs, 2007; Joiner, 2009a; 2009b; Lediju, 2016; Rizan et al., 2020).

Organizations need agile leaders so that company goals can be achieved (Lediju, 2016). This condition is required so that the organizations can become competitive and have an above average competitive advantage compared to their competitors (Detollenaere, 2017). A leader means someone who is in a position of authority that is appointed and someone who is given responsibility for managing the affairs of the organization as well as making decisions within specified limits (Rizan et al., 2020; Lediju, 2016). McKenzie \& Aitken (2012) added that agile leaders will have the skills to handle tensions caused by seemingly conflicting requirements. This can be done by reconciling local needs with collective interests, negotiating differences in individual and organizational performance priorities, and evaluating the sources of past success. Conducive conditions are needed for knowledge sharing, learning, engagement, and collaboration.

Joiner (2019) emphasized that leadership agility is able to play its role in creating an agile organization and is needed as a framework to understand that leadership agility can work within the organization. Yeh et al. (2016) examined the role of personality and leadership in influencing efficiency in the service organization environment. It turns out that both leadership and personality contribute to the success and failure of a unit and interact to moderate organizational performance. However, only openness can improve leader efficiency under a high initiation structure and low consideration leadership style. The results of the research also recommended personality as one of the factors that needs to be considered when choosing the leader of a work unit. Therefore, organizations need to choose the right person by making conformity between individuals and organizations 
which in turn can improve organizational performance. This was also strengthened by Ximenes et al. (2019) who said that entrepreneurial leadership has a role of a moderator in the relationship between high-performance work systems (HPWS) and employee creativity which makes an impact on employee performance. HPWS is a comprehensive work system that can vertically link with the company's business strategy, culture, and process of the company's organizational structure (Mihail et al., 2013).

H5. Leadership agility is able to moderate by strengthening the fit of the relationship between incremental innovation strategy and reactive personality toward service performance

H6. Leadership agility is able to moderate by strengthening the fit of the relationship between radical innovation strategy and proactive personality toward service performance

H7. Leadership agility is able to moderate by strengthening the fit of the relationship between incremental innovation strategy and mechanical organizational structure toward service performance

H8. Leadership agility is able to moderate by strengthening the fit of the relationship between radical innovation strategy and organic organizational structure toward service performance

\section{Research Methods}

The survey in this study is carried out with the population of managers of all-levels of the Islamic bank in two provinces, namely East Java and Yogyakarta. The population is selected with the following criteria: Islamic bank managers who work in private and public sector Islamic banks with an income of 15 million to 25 million per month; have worked for at least 5 years; and have worked at Islamic banks that have assets of 150 billion or more. The target sample consists of 250 respondents who work in the Islamic banks of these two provinces, namely East Java and Yogyakarta, and selected by using purposive sampling method. The questionnaires are distributed with the help of work partner's network who work in banking industry, bank manager associations, and Google Forms. The response rate obtained from this process is 73 percent.

Bipolar semantic differential scale approach is used in this study with the scale interval of 7 (very strongly suitable) to 1 (very strongly unsuitable). It is because this study uses two contingency variables, namely manager's personality (Pers) (reactive vs. proactive) and Organizational Structure (OS) (mechanical vs. organic). A contingency approach is used because it is crucial when it is linked to business strategy implementation by the companies (Delery \& Doty, 1996; Selto \& Renner, 1995). This study uses two contingency variables with different and conflicting typologies. As for service innovation strategy variable is concerned, it also has the same type of typologies, namely: incremental (Incr) vs. radical (Rad) service innovation strategy. To measure the company service performance, this study uses 5 indicators of service performance or SERVPERF, namely: time, accessibility, completeness, courtesy, and responsiveness that is measured using 7 point Likert scale (1/very low to 7/very high) compared to other similar company innovation services that belongs to the Islamic bank competitors.

Self-report can be done by the leader or manager (Miller 1987; Govindarajan 1988; Muafi \& Kusumawati 2020; Muafi, 2009; Edelman et al., 2005; Armstrong, 1992). This study is complemented by interviews with several Islamic bank managers both in East Java and Yogyakarta Province. This is done to complement the results of the study so that so that the outcome is good and qualitative. The contingency approach is analyzed with the Euclidience Distance (ED) statistical regression technique, and will be tested with Euclidience Distance (ED) moderation regression. Validity and reliability test results concluded that all items and variables are valid and reliable. The measurement for Euclidience Distance or the Misfit score between independent variable of service innovation strategy (incremental vs. radical) is obtained by examining each contingency variable, namely personality and organizational structure.

\section{Results}

\subsection{Description of Respondents}

The majority of respondents of this study is male (85\%), have worked for at least $5-10$ years $(61 \%)$, have bachelor degree $(52 \%)$, and tend to choose radical service innovation strategy $(62 \%)$.

\subsection{Hypothesis Testing}

The results for the hypothesis testing for hypothesis 1 to 8 using ED regression can be seen on Table 1. There are two groups of strategy, namely; incremental (code 1 with $\mathrm{n}=72$ ) and radical (code 2 with $\mathrm{n}=112$ ). Furthermore, the Euclidience Distance result is examined with service innovation performance. The statistic test results found that hypothesis 1 to 4 is accepted with the significance level less than 0.05 . The results of the test with ED moderation regression also conclude that partially, leadership agility is able to strengthen the fit of the relationship between incremental and radical strategy between reactive manager personality and mechanical organizational structure, and vice versa. This means that it supports hypothesis 5 to 8 (See Table 1). 
Table 1: The Summary of Regression Test Result

\begin{tabular}{|l|c|c|c|c|c|c|}
\hline Regression equation model & $\mathbf{N}$ & $\mathbf{R}^{2}$ & Constanta & $\begin{array}{c}\text { Coeffisients } \\
\text { (beta) }\end{array}$ & $\mathbf{t}$ & Sign \\
\hline H1. $\mathrm{Y}=\mathrm{a}+\mathrm{b} 1$ dist Increm.Person+e & 72 & 0.222 & 6.306 & -0.471 & -4.505 & $0.000^{*}$ \\
\hline H2. $\mathrm{Y}=\mathrm{a}+\mathrm{b} 1$ dist Increm.OS+e & 72 & 0.137 & 6.068 & -0.371 & -3.361 & $0.001^{*}$ \\
\hline H3. $\mathrm{Y}=\mathrm{a}+\mathrm{b} 1$ dist Increm.PersonZ+e & 72 & 0.160 & 6.083 & -0.400 & -3.674 & $0.000^{*}$ \\
\hline H4. $\mathrm{Y}=\mathrm{a}+\mathrm{b} 1$ dist Increm.OSZ+e & 72 & 0.220 & 6.274 & -0.469 & -4.479 & $0.000^{*}$ \\
\hline H5. Y = a + b1 dist Radic.Person+e & 112 & 0.262 & 6.260 & -0.262 & -2.855 & $0,005^{*}$ \\
\hline H6. $\mathrm{Y}=\mathrm{a}+\mathrm{b} 1$ dist Radic.SO+e & 112 & 0.230 & 6.296 & -0.230 & -2.495 & $0.014^{*}$ \\
\hline H7. Y = a + b1 dist Radic.PersonZ+e & 112 & 0.315 & 6.228 & -0.315 & -3.502 & $0.001^{*}$ \\
\hline H8. Y = a + b1 dist Radic.OSZ+e & 112 & 0.189 & 6.273 & -0.189 & -2.032 & $0.004^{*}$ \\
\hline
\end{tabular}

Note: *sign $<0.005$.

\subsection{Discussion}

The results of this study support all hypotheses that are supported. Islamic banking managers in the provinces of East Java and Yogyakarta tend to choose and implement radical rather than incremental service innovations. Nonetheless, the research results proved that there is a fit between the incremental service innovation strategy with reactive manager's personalty and mechanical organizational structure.

Partially, when there is a fit between incremental service innovation strategy with reactive personality and mechanical organizational structure, it will further improve service performance. and vice versa, when there is a fit between radical service innovation strategy with proactive personality and organic organizational structure, it will further enhance the performance of Islamic banking services. The results of this study also supports the previous research (Ashton, 1998; Bateman \& Crant, 1993) that individual personality will affect organizational performance when there is a fit with the chosen organizational strategy. Proactive personality is able to improve company performance when the managers can seize business opportunity well. Managers can make strategic decisions related to radical service innovation strategy orientation. When they make the decisions, managers should consider the time and costs that will be taken as well as the risks that is likely to emerge. Kickul \& Gundry (2002; Ahadiat 2003) suggested that the pressure from volatile and uncertain external environment forces managers to think and act proactively to capture the opportunities by creating organic organizational structures. It is because managers need to have highly flexible rules although they are exposed to high risks. Covid-19 pandemic has forced managers to make spectacular breakthroughs and flexible policies. Moreover, based on the research results, it is concluded that leadership agility is partially able to moderate the fit of the relationship between incremental innovation strategy with reactive personality and mechanical organizational structure. Leadership agility is also partially able to moderate the fit of the relationship between radical innovation strategy with proactive personality and organic organizational structure. It turns out that agile and smart leaders have the confidence to capture business opportunities which should be taken for the improvement in the service performance of the companies.

Currently, Islamic banking companies are faced with difficult situations. Covid-19 pandemic has forced the companies to have the ability to seize opportunities by minimizing their weaknesses as well as the threats they face. Some of the strategy of Islamic banking companies that can be applied to current situation is: First, start to revise the growth target due to the impact of the Covid-19 pandemic. The offer given to the customers as the best solution includes restructuring, increasing the financing period and giving a grace period of 3 to 6 months in the credit repayment. It is expected to help customers who are affected by the virus as a solution to the economic crisis. Second, Islamic banking managers must also see the threats and the problems that come along with this pandemic as an opportunity to improve their systems, especially from the point of view of the digital services. Socialization and education must continue to be provided to customers, especially those related to digital payments, so that customers do not feel inferior and afraid when making transactions, either payment or other transactions. Third, there are many opportunities for new financing and investments in fields related to the health sector such as masks, hospital ventilators, virus test kits, vaccines, and other health sector opportunities. Fourth, maintain the function of Islamic banks so that it is still carried out in accordance with the applicable rules, namely maintaining the intermediary function between the parties that hold funds with those who have the principle of profit sharing. The conformity of Islamic principles in bank operations must still 
be continued. It is done to maintain the trust and reputation as an Islamic bank. Managers should not let Islamic banks be considered bad because of poor management, and they should also not let it be considered like the conventional banks.

Ramdani et al. (2017) found that managers who have openness to experience and evaluate personalities tend to face the dynamic circumstances with innovative strategic choices instead of strategies that emphasize on the aspect of efficiency/cost leadership. Nadkarni \& Herrmann (2010) suggested that flexibility strategy is more recommended when managers or leaders have proactive orientation with lateral and flexible communication direction. Leaders should be more open and should be able to encourage, as well as have new and creative ideas which are needed to carry out radical innovation (Aronson et al., 2008). The research results from Aronson, et al. (2008; Waheed \& Dastgeer 2019) also concluded that managers with proactive personalities will have radical creativity. When choosing and implementing innovation strategies, managers must adjust to the stages of the company's business cycle (Hui \& Qing-xi 2006). It is very important so that managers do not make mistakes when making strategic decisions in improving company service performance. Managers also need to carefully consider the costs and benefits that will be generated, and therefore they will not experience failure. It is added by Sen \& Ghandforoush (2018; Abiodun 2017; Hui \& Qing-xi 2006) that managers who implement radical innovations are able to improve company performance and competitive advantage. Radical innovation can be carried out with product, process, and administration innovation. Service performance can be emphasized on the time dimension, accessibility, completeness, courtesy, and responsiveness.

Nevertheless, there are also a number of Islamic banking managers who still choose and implement incremental innovative strategies. Some of the consideratons turned out to be that they preferred to continue making changes in innovation by simply adding a few insignificant features in the products and services, and did not make significant changes to the organizational structure. In general, they face relatively tighter and very limited budget and time conditions. These conditions usually occurs with managers who work in public-owned Islamic banking. They tend to be careful and not careless while they still prioritize to provide satisfaction to their customers in improving service performance. They often discuss and agree to choose an innovation strategy that will be carried out before it is being introduced to customers.

It is in accordance with the theory and research conducted by Liu et al. (2010; De Simone 2017), that when companies are faced with the pressure of hostile and volatile external environment, they agree to carry out the business model with the same policy and strategy. It is done with the view that the customers can choose the products and services offered, because sometimes the customers get confused and insecure about the system changes offered if they are radically changed. Therefore, when a company chooses incremental innovation strategy, the company should use a mechanical organizational structure while remaining reactive to the situations, so that the company is able to improve service performance satisfactorily. On the contrary, when a company chooses radical innovation strategies, the company should have organic organizational structure by proactively seizing existing business opportunities as well as paying attention to the costs and time that have been allocated.

When leaders have leadership agility, they should be able to empower their staff and increase the role of the managers so that they continue to remain smart and agile in making decisions tailored to the innovation strategy that will be chosen. This can happen because of the different types of organizations and policies adopted by each Islamic banks belonging to both the private and public sectors. Leadership agility turns out to have the ability to strengthen the strategy agreement that is carried out because it has the ability to drive the company service performance both in incremental and radical innovation strategy. The efforts to improve employees' mobilization can be done by increasing their competence, especially those related to their respective work units by linking expertise in terms of information technology and digitalization. It needs to be done because by having knowledge and skills of good products and services, employees will be able to transfer their knowledge and skills to the customers well. Socialization and education to customers must be carried out continuously by utilizing social media through Whatsapp, Facebook, Twitter, Instagram, e-mail, and other types of social media.

\section{References}

Abiodun, T. S. (2017). An Examination of the Relationships Between Different Types of Innovation and Firm Performance and the Mediating Effect of Radical and Incremental Innovations on These Relationships. International Journal of Innovation and Economic Development, 3(5), 38-58.

Ahadiat, A. (2003). Organization Strategy, Structure, and Process. Jurnal Siasat Bisnis, 8(1), 83-93.

Allport, G. W. (1937). Personality: A psychological interpretation. New York, NY: Henry Holt.

Armstrong, M. (1992). Human Resources Management. Strategy and Action, London, UK: Kogan Page.

Armstrong, M. (2003). Strategic Human Resources Management. A Guide to Action. Jakarta, Indonesia: Terjemahan Gramedia.

Aronson, Z. H., Lynn, G., \& Reilly, R. R. (2008). The role of leader personality in new product development success: An examination of teams developing radical and incremental innovations. International Journal of Technology Management, 44(1/2), 5-27.

Ashton, M. C. (1998). Personality and job performance: The importance of narrow traits. Journal of Organizational Behavior, 19, 283-303. 
Banerjee, P., \& Cole, R. (2011). Globally radical technologies and locally radical technologies: The role of audiences in the construction of innovative impact in biotechnology. Transactions on Engineering Management, 58(2), 262-274.

Bateman, T. S., \& Crant, J. M. (1993). The proactive component of organizational behavior: A measure and correlates. Journal of Organizational Behavior, 14(2), 103-118.

Blau, P. M., \& Schoenhere, R. A. (1971). The structure of organizations, New York, NY: Basic Book, Inc.

Chandler, A. D. (1962). Strategy and Structure. In: Chapters in the History of the Industrial Entreprise, Cambridge, MA: MIT Press.

Chiew, K. S., \& Braver, T. S. (2011). Positive affect versus reward: Emotional versus motivational influences on cognitive control. Frontiers in Psychology, 19(2), 279. https://doi.org/10.3389/ fpsyg.2011.00279

Chiew, K. S., \& Braver, T. S. (2013). Temporal dynamics of motivation-cognitive control interactions revealed by highresolution pupillometry. Frontiers in Psychology, 4, 15. https:// doi.org/10.3389/fpsyg.2013.00015

Chiew, K. S., \& Braver, T. S. (2014). Dissociable influences of reward motivation and positive emotion on cognitive control. Cognitive, Affective, \& Behavioral Neuroscience, 14(2), 509-529.

Chiew, K. S., \& Braver, T. S. (2016). Reward favours the prepared: Incentive and task-informative cues interact to enhance attentional control. Journal of Experimental Psychology: Human Perception and Performance, 42(1), 52-66.

Covin, J. G., \& Slevin, D. P. (1989). Strategic Management of Small Firms in Hostile and Benign Environments. Strategic Management Journal, 10(1), 75-87.

Crant, J. M. (1995). The proactive personality scale and objective job performance among real estate agents. Journal of Applied Psychology, 80(4), 532-537.

Crant, J. M. (1996). The proactive personality scale as a predictor of entrepreneurial intentions. Journal of Small Business Management, 34(3), 42-49.

Crant, J. M. (2000). Proactive behavior in organizations. Journal of Management, 26(3), 435-462.

Crant, J. M., \& Bateman, T. S. (2000). Charismatic leadership viewed from above: The impact of proactive personality, Journal of Organizational Behavior, 21(1), 63-75.

Cronin, J. J., \& Taylor, S. A. (1994). SERVPERF versus SERVQUAL: Reconciling Performance-Based and Measurement of Service Quality. Journal of Marketing, 58(1), 125-132. https://doi.org/10.1177/002224299405800110

Cronin, J. J., \& Taylor, S. A. (1992). Measuring Service Quality: A Re-examination and Extension. Journal of Marketing, 56(July), 55-68.

David, F. R. (2001). Strategic Management. Concept and Cases. Upper Saddle River, NJ: Prentice Hall.
De Simone, S. (2017). Isomorphic Pressures and Innovation Trends in Italian Health Care Organizations, International Journal of Business and Management, 12(6), 26-32.

Delery, J. E., \& Doty, D. H. (1996). Modes of Theorizing in Strategic Human Resource Management: Tests of Universalistic, Contingency, and Configurational Performance Predictions, Academy of Management Journal, 39(4), 802-835.

Detollenaere, B. (2017). Agile Working and the Perceptive Understanding, The Influence on the Functioning of the Organization and How to Guide Employers. Master's Dissertation, Universiteit Teit.

Dewar, R. D., \& Dutton, J. E. (1986). The Adoption of Radical and Incremental Innovations: An Empirical Analysis, Management Science, 32(11),1422-1433.

Dharmayanti, D. (2006). Analysis of the Impact of Service Performance and Satisfaction as Moderating Variable on Customer Loyalty (Study on the Surabaya Branch of Bank Mandiri Savings Customers). Jurnal Manajemen Pemasaran, 1(1), 35-43.

Dubrin, A. J. (2013). Proactive Personality and Behaviour for Individual and Organizational productivity. London, UK; Edward Elgar Publishing Limited.

Edelman, L. F., Brush, C. G., \& Manolova, T. (2005). Co-alignment in the resource-performance relationship: Strategy a mediator, Journal of Business Venturing, 20(3), 359-383.

Feist, J., \& Feist, G. J. (2008). Theories of Personality ( $7^{\text {th }}$ ed.). New York, NY: McGraw and Hill.

Govindarajan, V. (1988). A contingency approach to strategy implementation at the business unit level: Integrating administrative mechanism with strategy, Academic of Management Journal, 31, 828-853.

Gronum, S., Verreynne, M. L., \& Kastelle, T. (2012). The Role of Networks in Small and Medium-Sized Enterprise Innovation and Firm Performance. Journal of Small Business Management, 50(2), 257-282.

Hage, J., \& Aiken, M. (1969). Routine technology, social structure and organizational goals, Administrative Science Quarterly, 14, 366-376.

Hall, R. H. (1972). Organization Structure and process. Englewood Cliffs, NJ: Prentice Hall.

Hartanto, S., \& Sugandha, A. C. (2019). Incremental innovation as a strategy \& competitive advantage in the Vietnamese furniture industry (case study: full in industrial, co., Ltd). Dimensi, $16(1), 59-74$.

Hilda, N. (2014). Service Innovation Strategy in Improving Service Quality in Surabaya City Land Office II. Kebijakan dan Manajemen Publik, 2(1), 1-10.

Hodge, B. J., Anthony, W. P., \& Gales, L. M. (2003). Organization theory: A strategic approach (6th ed.). Englewood Cliffs, NJ: Prentice Hall.

Hui, Q., \& Qing-Xi, W. (2006). Radical Innovation or Incremental Innovation: Strategic Decision of Technology-intensive Firms 
in the PRC. In: IEEE International Engineering Management Conference (pp. 327-331). Bahia.

Hutagalung, C. (2016). The Effect of Leadership Style Moderators on the Influence of Motivation on Employee Performance. Universitas Sanata Dharma Yogyakarta, Indonesia.

Jannah, (2016). The Relationship between Hippocratic Personality and Anxiety Levels. Universitas Aisyiyah Yogyakarta, Indonesia.

Joiner, B. (2009a). Guide to Agile Leadership. Industrial Management, 51(2), 10-15.

Joiner, B. (2009b). Creating a culture of agile leaders: A developmental approach. People and Strategy, 32(4), 28-35.

Joiner, B. (2019). Leadership Agility for Organizational Agility. Journal of Creating Value, 5(4), 1-11.

Joiner, B., \& Josephs, S. (2007). Leadership Agility, Five Levels of Mastery for Anticipating and Initiating Change. Hoboken, NJ: John Wiley \& Sons, Inc.

Kartika, T., Firdaus, A., \& Najib, M. (2020). Contrasting the Drivers of customer Loyalty; Financing and Depositor Customer, Single and Dual Customer, In Indonesian Islamic Bank, Journal of Islamic Marketing, 11(4), 933-959.

Kenzie, J., \& Aitken, P. (2012). Learning to lead the Knowledgeable Organization: Developing Leadership Agility, Strategic HR Review, 11(6), 329-334.

Kickul, J., \& Gundry, L. (2002). Prospecting for Strategic Advantage: The Proactive Entrepreneurial Personality and Small Firm Innovation, Journal of Small Business Management, 40(2), 85-97.

Koeswara, E. (1991). Theories of Personality. Bandung, Indonesia: Penerbit PT Eresco.

Kumar, K., Subramanian, R., \& Yauger, C. (1997). Pure versus Hybrid: Performance Implications of Porter's generic Strategies, Health Care Management Review, 22(4), 47-60.

Kumari, N. (2018). Organizational Diagnosis: A Case of Infosys, India. Journal of Asian Finance, Economics and Business, 5(1), 53-62. https://doi:10.13106/jafeb.2018.vol5.no1.53

Lediju, T. (2016). Leadership agility in the public sector: understanding the Impact of public sector managers on the organizational Commitment and performance of millennial employees. PhD Dissertation, Saybrook University, Oakland, California.

Lestari, Y. D., \& Laode, M. I. (2018). Service Innovation of 3/2 Star Hotel in Bandung. Journal of Asian Finance, Economics and Business, 5(3), 73-80. https://doi:10.13106/jafeb.2018.vol5. no3.73

Liu, D., Liang, Y., \& Zhang, Y. (2010). The effects of human capital on competitive strategies and performance Evidence from listed companies in China's SME board. In: Proceeding of IEEE International Conference on Management of Innovation \& Technology (pp. 670-675).

McKenzie, J., \& Aitken, P. (2012). Learning to lead the knowledgeable organization: Developing leadership agility. Strategic HR Review, 11(6), 329-334.
Mihail, D. M., Links, M. M., \& Sarvanidis, S. (2013). High Performance Work Systems in Corpo-rate Turnaround: A German Case Study, Journal of Organizational Change Management, 26(1), 190-216.

Miles, R. E., \& Snow, C. C. (1978). Organization Strategy, Structure and Process. New York, NY: McGraw-Hill.

Miller, D. (1987). Strategy Making and structure: Analysis and implication for performance. Academic of Management Journal, 30, 7-32

Muafi, \& Kusumawati, R. A. (2020). Strategic consensus on organizational performance: A contingency approach of organizational culture and isomorphic pressure. Journal of Industrial Engineering and Management, 13(1), 352-370.

Muafi. (2009). The Effects of Alignment Competitive Strategy, Culture, and Role Behavior on Organizational Performance in Service Firms. The International Journal of Organizational Innovation, 1(4), 74-100.

Muafi, \& Uyun, Q. (2018). Influence on The Organizational Learning and Organizational Innovation and How to Reduce Imitation Orientation. International Journal for Quality Research, 13(2), 467-484.

Muafi, Susilowati, C., \& Wijayani, A. (2020). The Fit of Personality-Strategy-Environment and Business Performance. International Journal of Advanced Science and Technology, 29(3), $5605-5610$.

Muluk, K. M. R. (2008). Knowledge Management. Jakarta, Indonesia: Bayu Media-FIA UNIBRAW.

Nadkarni, S., \& Herrmann, P. (2010). CEO personality, strategic flexibility, and firm performance: The case of the Indian business process outsourcing industry. The Academy of Management Journal, 53(5), 1050-1073.

Negandhi, A. R. (1975). Comparative Management and Organization Theory: A Marriage Needed, Academy of Management Journal, 18(2), 334-344.

Ramdani, D., Hermans, J., Vanderstraeten, J., \& Dejardin, M. (2015). The fit of manager personality traits-strategyenvironment and organizational performance. Academy of Management Proceedings, 1, 16237.

Robbins, S. P., \& Judge, T. A. (2013). Organizational Behavior. Englewood Cliffs, NJ: Prentice Hall.

Robbins, S. P. (1991). Organizational Behavior. Englewood Cliffs, NJ: Prentice Hall.

Robbins, S. P., \& Coulter, M. (2012). Management (11th ed.) Englewood Cliffs, NJ: Prentice Hall.

Rizan, M., Warokka, A., Wibowo, A., \& Febrillia, I. (2020). Leadership Styles and Customer Loyalty: A Lesson from Emerging Southeast Asia's Airlines Industry. Journal of Asian Finance, Economics and Business, 7(9), 477-488. https:// doi:10.13106/jafeb.2020.vol7.no9.477

Sari, S. R. (2018). Employee Conflict and Performance: The Role of Leadership Style moderation. Jurnal Riset Manajemen dan Bisnis, 3(1), 431-440. 
Schuler, R. S., \& Jackson, S.E. (1987). Linking competitive strategy with Human Resources Management Practices, Academic of Management Executive, 1(3), 207-219.

Selto, F. H., \& Renner, C.J., (1995). Assessing The Organizational Fit Of A Just In Time Manufacturing System; Testing Selection, Interaction and System Models Of Contingency Theory. Accounting Organizations and Society, 20(7/8), 665-684.

Sen, T. K., \& Ghandforoush, P. (2018). Radical and Incremental Innovation Preferences in Information Technology: An Empirical Study in an Emerging Economy. Journal of Technology Management \& Innovation, 6(4S), 33-44.

Setiawan, S. A., \& Puspitasari, N. (2018). Preference of Organizational Structure for Millennial Generation. Jurnal Borneo Administrator, 14(2), 101-118.

Soebachman A. (2011). The Art of Reading Human Character and $I Q$. Yogyakarta, Indonesia: IN AzNa Books.

Soleh, M. (2008). Analysis of Innovation Strategies and their Impact on Company Performance (Case Study: Manufacturing SMEs in Semarang City). Universitas Diponegoro, Semarang, Indonesia.

Steers, R. M. (1980). Organizational Effectiveness. Jakarta, Indonesia: Erlangga.
Steers, R. M. (1977). Organizational Effectiveness, A Behavioral View. Santa Monica, CA: Goodyear Publishing Company, Inc.

Suryabrata, S. (2019). Psychology of Personality. Jakarta, Indonesia: CV Rajawali

Waheed, H., \& Dastgeer, G. (2019). The impact of proactive personality on radical and incremental creativity: an interactionist perspective, Amazonia Investiga, 8(20), 706-718

Wu, C., Siswanto, I. K.C.., Minghat, A. D., \& Mustakim, S. S. (2018), The Proactivity of Academic Elites: A Systematical Approach to Proactive Behavior Development in University Setting. The Turkish Online Journal of Design, Art and Communication, Special Edition, 1636-1648.

Ximenes, M., Supartha, W. G., Dewi, I.G.A.M., \& Sintaasih, D. K. (2019). Entrepreneurial leadership moderating high performance work system and employee creativity on employee performance. Cogent Business \& Management, 6,1. DOI: $10.1080 / 23311975.2019 .1697512$

Yeh, S. C. J., Chen, S. H. S., Chou, H. C., Chiu, H. C., Yuan, K. S., Lo, Y. Y., Huang, S., \& Wan, T. T. H. (2016). The moderating effect of leadership on the relationship between personality and performance. Journal of Nursing Management, 24(7), 1-15. 